Piotr Tylec

Biblioteka Diecezjalna w Sandomierzu

\title{
Inwigilacja duchowieństwa diecezji sandomierskiej w świetle dokumentu KW MO w Kielcach z dnia 6 października 1961 roku
}

Jednym z zadań, jakie stawiała sobie komunistyczna władza w okresie Polskiej Rzeczpospolitej Ludowej, było rozpoznawanie „wrogiej działalności" członków społeczeństwa i eliminowanie jej poprzez stosowanie różnego rodzaju represji. Działania te nie ominęły również Kościoła katolickiego, a szczególnie osób duchownych. Dla komunistów było jasne, iż ci, którzy kierują sumieniami wiernych, sprzeciwiają się ideologii marksistowskiej, która godziła w podstawy doktryny chrześcijańskiej. Dlatego kapłani zostali poddani szczególnej inwigilacji, zwłaszcza ze strony aparatu bezpieczeństwa. W tym celu funkcjonariusze bezpieki stosowali odpowiednie metody pracy operacyjnej. Należy do nich rozpracowanie agenturalne oraz agenturalno-operacyjna obserwacja ${ }^{1}$. Druga z tych metod polegała na stałym kontrolowaniu działalności osób, które w przekonaniu funkcjonariuszy organów bezpieczeństwa mogły podjąć działania antysystemowe². Takiej stałej obserwacji zostali poddani również duchowni rzymskokatolickiej diecezji sandomierskiej.

1. Instrukcja nr o3/55 o zasadach prowadzenia rozpracowania agenturalnego $i$ ewidencji operacyjnej w organach bezpieczeństwa publicznego PRL, Warszawa, 11 III 1955, w: Instrukcje pracy operacyjnej aparatu bezpieczeństwa (1945-1989), oprac. i wstęp T. Ruzikowski, Warszawa 2004, s. 47.

2. F. Musiał, Podręcznik bezpieki. Teoria pracy operacyjnej Służby Bezpieczeństwa w świetle wydawnictw resortowych Ministerstwa Spraw Wewnętrznych PRL (197o-1989), Kraków 2007, s. 310.

Piotr Tylec, Inwigilacja duchowieństwa diecezji sandomierskiej... 
W latach 1946-1955 funkcjonariusze Wojewódzkiego Urzędu Bezpieczeństwa Publicznego w Kielcach prowadzili sprawę obiektową o kryptonimie "Flora". W jej ramach działaniami operacyjnymi objęto Kurię Diecezjalną w Sandomierzu oraz duchownych diecezji sandomierskiej, którzy posługiwali na terenie województwa kieleckiego ${ }^{3}$. Sprawa ta była prowadzona do połowy 1955 r., kiedy to WUBP w Kielcach wdrożył przepisy zawarte w Instrukcji KdsBP nr 03/55 „o zasadach prowadzenia rozpracowania agenturalnego i ewidencji operacyjnej w organach bezpieczeństwa publicznego PRL" z 11 marca 1955 r. Rozpoczęto wówczas gromadzenie informacji na temat Kościoła katolickiego w ramach teczek zagadnieniowych. Założono je i prowadzono we wszystkich powiatach województwa kieleckiego ${ }^{4}$.

Oddzielną sprawą objęto Kurię Diecezjalną w Sandomierzu oraz seminarium duchowne w tymże mieście. Kwestią tą zajął się referent Sekcji I Wydziału VI WUBP w Kielcach ppor. Zdzisław Prokop. Funkcjonariusz ten wniosek o założenie odpowiedniej teczki zagadnieniowej wniósł 10 maja 1955 r., pisząc w nim: „Księża kurialiści i profesorowie seminarium duchownego w Sandomierzu stanowią trzon reakcyjnej części kleru na terenie diecezji, który zwalcza nie tylko postępową część księży, ale również inspirują podległy kler do odciągania ludzi wierzących od realizacji polityki Partii i Rządu"5. Charakter tej sprawy zmienił się nieco w lipcu 1959 r., kiedy to starszy oficer operacyjny Grupy V Wydziału III Komendy Wojewódzkiej Milicji Obywatelskiej w Kielcach kpt. Jan Walaszczyk sporządził postanowienie o założenie (w praktyce kontynuowanie) teczki zagadnieniowej.

3. R. Szczypta-Szczęch, Powiatowy Urząd Bezpieczeństwa Publicznego Opatów z siedziba w Ostrowcu Świętokrzyskim wobec Kościoła katolickiego w latach 1945-1955, w: Aparat represji wobec Kościoła w latach 1944-1956. Terytorium obecnej diecezji sandomierskiej, red. M. Krzysztofiński, J. Marecki, B. Stanaszek, Kraków 2012, s. 52 .

4. Archiwum Instytutu Pamięci Narodowej - Komisja Ścigania Zbrodni przeciw Narodowi Polskiemu, Delegatura w Kielcach [dalej: AIPN Ki], sygn. 015/819, Postanowienie o założeniu teczki zagadnieniowej dot. kleru świeckiego, zakonnego i sekt religijnych pow. ostrowieckiego, Ostrowiec Świętokrzyski, 21 V 1955, k. 605. Inicjatywę tę powtórzono po „odwilży październikowej" w kwietniu 1958. AIPN Ki, sygn. 015/679, t. 1, Postanowienie o założeniu teczki zagadnieniowej dot. kleru świeckiego i zakonnego oraz aktywu katolickiego pow. sandomierskiego, Sandomierz, 21 IV 1958, k. 3; AIPN Ki, sygn. 015/819, Postanowienie o założeniu teczki zagadnieniowej dot. kleru świeckiego oraz zakonnego i aktywu katolickiego pow. ostrowieckiego, Ostrowiec Świętokrzyski, 12 IV 1958, k. 606.

5. AIPN Ki, sygn. 015/824, t. 1, Postanowienie o założeniu teczki zagadnieniowej dot. kurii i seminarium duchownego w Sandomierzu, Kielce, 10 V 1955, k. 4. 
Funkcjonariusz ten oprócz kurii i seminarium chciał skierować swoją uwagę również na „reakcyjny kler na terenie diecezji sandomierskiej". Zaznaczał on jednak, iż praca operacyjna będzie się koncentrować głównie wokół dwóch pierwszych instytucji kościelnych ${ }^{6}$. Sprawie tej nadano wówczas kryptonim „Wisła"7. Omawiana teczka zagadnieniowa była uzupełniana do 22 listopada $1965 \mathrm{r}^{8}$, kiedy to zdecydowano się na kontynuowanie obserwacji jedynie w ramach ujednoliconego systemu dokumentacji operacyjnej duchowieństwa - czyli tzw. teczek ewidencji operacyjnej na księdza (TEOK) i teczek ewidencji operacyjnej na parafię (TEOP) ${ }^{9}$.

Prezentowany dokument źródłowy (Ocena sytuacji operacyjnej na odcinku kleru parafialnego diecezji sandomierskiej oraz kierunkowy plan operacyjnych przedsięwzięć) pochodzi z dokumentacji aktowej opisanej sprawy. Znalazł się on w jej pierwszym tomie (Kontrwywiadowcza charakterystyka zagadnienia). Charakterystyki te były elementem wyróżniającym teczki zagadnieniowe, nie było ich bowiem w podobnych teczkach obiektowych. Uwzględniano w nich metody i środki działania inwigilowanej grupy osób oraz ich profil polityczny. Dodatkowo mógł się tam znaleźć "kierunkowy plan operacyjnych przedsięwzięć". Tego typu charakterystyki i oceny pozwalały na szybkie poznanie problematyki danej sprawy. Funkcjonariusz bezpieki, który chciał mieć ogólną orientację o danej grupie osób, nie musiał zapoznawać się z całością dokumentacji, wystarczyło, iż sięgnął po sporządzone charakterystyki ${ }^{10}$.

6. AIPN Ki, sygn. 015/824, t. 1, Postanowienie o założeniu teczki zagadnieniowej dot. kurii, seminarium duchownego w Sandomierzu oraz reakcyjnej części kleru na terenie diecezji sandomierskiej, Kielce, 24 VII 1959, k. 5.

7. AIPN Ki, sygn. 015/824, t. 1, Kontrwywiadowcza analiza sytuacji operacyjnej na obiekcie oraz perspektywiczny plan operacyjny przedsięwzięć w sprawie obiektowej krypt. „Wisła", Kielce, 2 V 1961, k. 52-81.

8. AIPN Ki, sygn. 015/824, t. 1, Postanowienie o zaniechaniu prowadzenia teczki zagadnieniowej nr rej. 598/62 na kler kurialny diec. sandomierskiej i złożenia materiałów w archiwum Wydziału "C", Kielce, 22 XI 1965, k. 121.

9. Zarzadzenie nr oo114/63 ministra spraw wewnętrznych $w$ sprawie prowadzenia ewidencji i dokumentowania działalności kleru katolickiego oraz instrukcja nr oo2/63 dyrektora Departamentu IV i dyrektora Biura "C" MSW o zasadach i trybie prowadzenia ewidencji i dokumentowania działalności kleru katolickiego, Warszawa, 6 VII 1946, oprac. Ł. Marek, w: Metody pracy operacyjnej aparatu bezpieczeństwa wobec Kościołów i związków wyznaniowych 1945-1989, red. A. Dziurok, Warszawa 2004, s. 336-345.

10. F. Musiał, Podręcznik bezpieki..., dz. cyt., s. 258, 311 . 
Dotychczas z materiałów rozpracowania Kurii Diecezjalnej w Sandomierzu i seminarium duchownego w tymże mieście korzystała mała liczba badaczy. Przez długi czas dostęp do nich był utrudniony poprzez mało precyzyjny spis jednostek archiwalnych byłego Wojewódzkiego Urzędu Spraw Wewnętrznych w Kielcach. Teczki były zatytułowane w taki sposób, iż prawie nie wskazywały na ich zawartość (np. „brak danych", „mat[eriały] operacyjne", itp. ${ }^{11}$. Dlatego też prezentowany dokument źródłowy może stać się ciekawym przykładem jednego z podstawowych elementów teczek zagadnieniowych. Dodatkowo w sposób precyzyjny wskazuje na skalę inwigilacji duchowieństwa diecezji sandomierskiej na początku lat 6o. Być może stanie się on zachętą do podjęcia kolejnych badań nad dziejami Kościoła w PRL, a szczególnie na terenie dawnego województwa kieleckiego i wspomnianej diecezji.

Dokument zaczerpnięty z teczki zagadnieniowej o kryptonimie „Wisła" został przez autora poddany edycji według Materiałów do instrukcji wydawniczej dla źródeł do dziejów najnowszych Polski, opracowanych przez Stanisława Kalabińskiego i Feliksa Tycha w 1958 r. ${ }^{12}$ Poza tym wykorzystano przepisy zawarte w książce Edytorstwo Źródeł Historycznych, wydanej przez Instytut Historii Polskiej Akademii Nauk w 2014 r. ${ }^{13}$

11. R. Szczypta-Szczęch, Powiatowy Urzad..., dz. cyt., s. 136 (Komunikat dotyczący akt sprawy obiektowej o kryptonimie „Flora"). Do materiałów tych nie dotarł ks. Bogdan Stanaszek, przy pisaniu monografii Diecezja Sandomierska w powojennej rzeczywistości politycznej 1945-1967 (kwerenda prowadzona była przed 2005 r.).

12. Materiały do instrukcji wydawniczej dla źródeł do dziejów najnowszych Polski, oprac. S. Kalabiński, F. Tych, Warszawa 1958 (maszynopis powielany).

13. J. Tandecki, K. Kopiński, Edytorstwo Źródeł Historycznych, Warszawa 2014, S. $204-211$. 


\section{Dokument}

„ZATWIERDZAM"a

${ }^{\mathrm{b}}$ Kielce, dnia 6.X.1961r.

Tajne spec[jalnego] znacz[enia]

Egz. $\operatorname{Nr}^{\mathrm{c}}$

\section{OCENA}

sytuacji operacyjnej na odcinku kleru parafialnego diecezji sandomierskiej oraz kierunkowy plan operacyjnych przedsięwzięć

Diecezja sandomierska swym zasięgiem terytorialnym obejmuje obszar 13 powiatów wchodzących w skład woj. kieleckiego a to: sandomierski, opatowski, starachowicki, lipski, konecki, opoczyński, szydłowiecki, przysuski, radomski, białobrzeski, kozienicki, zwoleński i staszowski oraz część pow[iatu] kieleckiego ze Skarżyskiem włącznie. Podział administracyjny województwa nie odpowiada podziałowi administracyjnemu diecezji sandomierskiej, na terenie której, znajduje się 27 dekanatów, 174 parafie i 578 księży świeckich i zakonnych, w tym 518 księży świeckich i 60 zakonnych.

W rozbiciu na księży pozytywnych, biernych i wrogo ustosunkowanych do ustroju i władzy PRL ${ }^{14}$, stan ten przedstawia się następująco:
a. 83 księży pozytywnych
b. 348 biernych
c. 138 księży negatywnych i wrogo ustosunkowanych
d. 9 księży nierozpoznanych

a. Poniżej odręcznie wpisana data [...] X $1962 \mathrm{r}$. oraz nieczytelny podpis.

b. Obok pieczęć - czerwony kwadrat $\mathrm{z}$ literą "F" w środku. Pieczęć ta pojawia się na wszystkich kartach dokumentu powyżej zawartego tam tekstu maszynowego.

c. Cyfra wpisana odręcznie wmiejscu podkreślonym maszynowo.

14. Od chwili uchwalenia Dekretu o ochotnie wolności sumienia i wyznania (5 VIII 1949) w dokumentacji aparatu bezpieczeństwa, władz administracyjnych i partyjnych przy nazwiskach poszczególnych księży zaczęto dopisywać określenia: „pozytywny", „bierny", „wrogi", „nierozpoznany". Terminy te miały odpowiadać postawom politycznym poszczególnych duchownych. J. Stefaniak, Postawy duchowieństwa w ocenie władz państwowych w latach apogeum stalinizmu (1948-1956), w: Społeczeństwo - Państwo - Kościół (1945-20oo). Materiały z ogólnopolskiej konferencji naukowej, Szczecin, 15-16 VI 2000 r., red. A. Kawecki, K. Kowalczyk, A. Kubaj, Szczecin 2000, s. 17. 
d. W oryginale: Z pośród.
Spośród ${ }^{\mathrm{d}} 348$ księży biernie ustosunkowanych oraz 138 księży o wrogim stosunku do PRL aktualnie prowadzonych jest 58 spraw kategorii operacyjnej obserwacji ${ }^{15}$, z tego 3 sprawy na 8 księży kurialistów i biskupów przez grupę V-tą Wydziału III-go ${ }^{16}$, oraz 55 spraw na kler dołowy ${ }^{17}$ przez poszczególne jednostki Służby Bezpieczeństwa. Obok tego prowadzonych jest 10 spraw na aktyw katolicki ${ }^{18}$. Ogółem do obserwacji tych figurantów ${ }^{19}$ spraw oraz ustalenia polityki kurii i przeciwdziałania wrogiej działalności kleru wykorzystywanych jest 29 tajnych współpracowników ${ }^{20}$ wywodzących się spośród kleru i 33 tajnych współpracowników wywodzących się z osób świeckich, a szczególnie z aktywu katolickiego.

Poza tym wykorzystywanych jest $135 \mathrm{k}$ [ontaktów] p[oufnych] ${ }^{21} \mathrm{z}$ tego 62 księży i 73 osób świeckich.

15. Sprawa operacyjnej obserwacji (ewidencyjno-obserwacyjna) - była prowadzona w celu systematycznego kontrolowania zachowań osób, które zdaniem funkcjonariuszy bezpieki mogły podjąć działania antysystemowe. F. Musiał, Podręcznik bezpieki..., dz. cyt., s. 346 .

16. W okresie od 27 XI 1956 do 9 VI 1962 w strukturach aparatu bezpieczeństwa kwestiami Kościoła katolickiego zajmował się Wydział V Departamentu III Ministerstwa Spraw Wewnętrznych. Na poziomie wojewódzkim odpowiadały mu Grupy V Wydziałów III KW MO. A. Dziurok, Wstęp, w: Metody pracy operacyjnej aparatu bezpieczeństwa wobec Kościołów i związków wyznaniowych 1945-1989, Warszawa 2004, s. 23-24.

17. Kler dołowy - duchowieństwo diecezjalne nienależące do hierarchii kościelnej (zakonnicy niekierujący swoim zgromadzeniem). Natomiast biskupów, kurialistów, profesorów seminariów duchownych i innych urzędów diecezjalnych nazywano „klerem wyższym". Bezpieka przejęła termin „kler dołowy” z języka komunistycznej propagandy, gdzie osobnicy „dołowi" mieli być bardziej lojalni wobec „władzy ludowej". R. Graczyk, Tropem SB. Jak czytać teczki, Kraków 2007, s. 23.

18. Aktyw katolicki - świeccy działacze katoliccy. Szczególną inwigilacją bezpieka starała się otoczyć osoby przynależące do różnego rodzaju organizacji kościelnych i utrzymujące kontakty towarzyskie z duchowieństwem. R. Graczyk, Tropem $S B \ldots$, dz. cyt., s. 22.

19. Figurant - osoba inwigilowana przez bezpiekę, wobec której podejmowano działania operacyjne (m.in. obserwacja, rozmowy ostrzegawcze, itp.). F. Musiał, Podręcznik bezpieki..., dz. cyt., s. 330, 348 .

20. Tajny współpracownik - jedna z kategorii osobowych źródeł informacji, która funkcjonowała w 1. 1960-1990. Była to osoba celowo zwerbowana do współpracy z SB, wykonująca zlecone jej zadania.

21. Kontakt poufny - jedna z kategorii osobowych źródeł informacji, która funkcjonowała w l. 1955-1960. Była to osoba lojalna wobec komunistów i stopniowo pozyskiwana do współpracy. Choć osoba ta nie została jeszcze formalnie zwerbowana, była świadoma swoich kontaktów z funkcjonariuszami SB, dostarczała konkretne informacje, a nawet mogła wykonywać zlecone zadania. Ł. Kamiński, Lingua securitatis, „Pamięć i Sprawiedliwość" 2003 nr 1 (3), s. 211; F. Musiał, Podręcznik

Folia Historica Cracoviensia, t. 23, z. 2 (2017) 
W rozbiciu na poszczególne powiaty stan prowadzonych spraw i naszych możliwości operacyjnych przedstawia następujące zestawienie:

\begin{tabular}{|c|c|c|c|c|c|c|}
\hline \multirow[t]{2}{*}{$\begin{array}{l}\text { Nazwa } \\
\text { powiatu }\end{array}$} & \multicolumn{2}{|c|}{ Ilość spraw } & \multicolumn{2}{|c|}{$\begin{array}{l}\text { Ilość t[ajnych] } \\
\text { w[spółpracowników] }\end{array}$} & \multicolumn{2}{|c|}{$\begin{array}{l}\text { Ilość k[ontaktów] } \\
\text { p[oufnych] }\end{array}$} \\
\hline & Na kler & $\begin{array}{l}\text { Na ak- } \\
\text { tyw }\end{array}$ & Księży & $\begin{array}{l}\text { Osób } \\
\text { świeckich }\end{array}$ & Księży & $\begin{array}{l}\text { Osób } \\
\text { świeckich }\end{array}$ \\
\hline Grupa V-ta & 3 & - & 5 & - & 6 & 2 \\
\hline Radom & 7 & 3 & 6 & 3 & 8 & 7 \\
\hline Sandomierz & 3 & - & 2 & 2 & 3 & 8 \\
\hline Ostrowiec & 9 & - & 3 & 6 & 5 & 7 \\
\hline Starachowice & 2 & - & 3 & 2 & 9 & 8 \\
\hline Skarżysko & - & 2 & 2 & 3 & 1 & 3 \\
\hline Końskie & 3 & - & 1 & 1 & 6 & 7 \\
\hline Opoczno & 8 & - & 1 & 4 & 2 & 6 \\
\hline Przysucha & 3 & 1 & 1 & 3 & 2 & 6 \\
\hline Szydłowiec & 4 & - & - & 1 & 4 & 3 \\
\hline Białobrzegi & 7 & 2 & - & 5 & 3 & 2 \\
\hline Kozienice & 5 & - & 3 & 1 & 2 & 4 \\
\hline Zwoleń & 3 & - & - & - & 1 & 6 \\
\hline Staszów & 1 & 2 & 2 & 2 & 4 & 5 \\
\hline Razem: & 58 & 10 & 29 & 33 & 62 & 73 \\
\hline
\end{tabular}

Oceniając celowość prowadzonych spraw i ich wartość operacyjną, stwierdzić należy, że na ogólną liczbę 58 spraw na księży przypada: 3 biskupów, 5 księży kurialistów i profesorów sem[inarium] duch[ownego], 11 dziekanów i wicedziekanów, 7 członków kapituł oraz 36 proboszczów i wikariuszów.

Na dwie istniejące kapituły - przy bazylice sandomierskiej i kolegiacie opatowskiej, liczących ogółem 44 księży kanoników, spośród których na 7 prowadzone są sprawy, wykorzystywanych jest aktualnie $5 \mathrm{t}$ [ajnych]

bezpieki..., dz. cyt., s. 334; F. Musiał, Raj grabarzy narodu. Studia i materiały do dziejów aparatu represji w Polsce "ludowej" 1945-1989, Kraków 2010, s. 140. 
w[spółpracowników] a to: „Grzegorz"22, "B-5"23, "J-10"24, „Wacław"25 i „Zefir" $^{\prime 26}$. Ponadto wykorzystywanych jest 8 kontaktów poufnych a to: G.E., K.S., J.J., Sz.S., S.K., N.Wł., B.J. i Z.A.

Na rozbiciu na poszczególne kapituły, stan powyższy przedstawia się następująco: na 26 księży z kapituły sandomierskiej 5 objętych jest sprawami kategorii operacyjnej obserwacji. Do obserwacji figurantów tych spraw wykorzystywanych jest 4 kontakty poufne, wywodzących się z członków tejże kapituły, a to: G.E., Z.A., K.S., J.J. Tajnych współpracowników wśród członków omawianej kapituły dotychczas nie ma. Znacznie lepiej sytuacja wygląda pod względem operacyjnego zabezpieczenia dopływu informacji o figurantach spraw oraz planach, zamierzeniach i działalności członków kapituły kolegiaty opatowskiej. Na 17 księży, członków tejże kapituły prowadzone są 2 sprawy kategorii operacyjnej obserwacji, oraz wykorzystywanych jest aktualnie 5 tajnych współpracowników i 4 kontakty poufne. Są to: t[ajni] w[spółpracownicy] „J-10", ,Zefir", „B-5", „Wacław" i „Grzegorz" oraz k[ontakty] p[oufne] Sz.S., S.K., N.W. i B.J.

Obok tego na 27 dziekanów i 30 wicedziekanów z terenu diecezji sandomierskiej na $11 \mathrm{z}$ nich prowadzone są sprawy oraz wykorzystywanych jest wśród nich 5 tajnych współpracowników, oraz 8 kontaktów poufnych.

22. Aktualny stan badań nie pozwala na określenie, kim był tajny współpracownik o pseudonimie "Grzegorz".

23. Ks. Jan Koziński - ur. 16 V 1893 w Dzierszynie. Święcenia kapłańskie przyjął 30 VII 1916. Od 1952 był proboszczem i dziekanem w Końskich, gdzie zmarł 12 VIII 1976. Kronika Diecezji Sandomierskiej [dalej: KDS] 70 (1977), s. 69-70; B. Stanaszek, R. Nowakowski, Słownik biograficzny księży diecezji sandomierskiej XIX-XX W., t. 2, H-Ł, Sandomierz 2005 [dalej: SBKDS, t. 2], s. 141-142. Pozyskany do współpracy z aparatem bezpieczeństwa jako informator „B-5" 13 XII 1952. Wyeliminowany z sieci agenturalnej 29 XII 1954, jednak został ponownie pozyskany 5 XII 1955. AIPN Ki, sygn. 015/824, t. 5, Charakterystyka informatora ps. „B-5" nr rej. 2362, Kielce, 9 I 1960, k. 87-89; M. Klocek, Prześladowanie duchowieństwa katolickiego w Końskich w latach 1939-1989, Końskie 2013, s. 80-82.

24. Informator "J-10" - kapłan pracujący w powiecie radomskim, podjął współpracę z bezpieką po 1959. AIPN Ki, sygn. 015/824, t. 5, Wykaz agentury wykorzystywanej po zagadnieniu kleru z diecezji sandomierskiej, Kielce, 30 XII 1959, k. 80.

25. Podobnie jak w przypadku tajnego współpracownika o pseudonimie "Grzegorz", nie jest obecnie możliwe określenie personaliów tego informatora SB.

26. Informator "Zefir" - kapłan pracujący w powiecie skarżyskim, podjął współpracę z bezpieką w 1958. AIPN Ki, sygn. 015/824, t. 5, Wykaz agentury wykorzystywanej po zagadnieniu kleru z diecezji sandomierskiej, Kielce, 30 XII 1959, k. 81. 
Jeżeli chodzi o najbardziej wrogie grupy księży lub poszczególne pojedyncze jednostki, to ich rozmieszczenie na terenie tej diecezji przedstawia się następująco:

\section{Radom:}

[Andrzej] Łukasik ${ }^{27}$, [Jan] Chaczek ${ }^{28}$, [Stanisław] Warchoł ${ }^{29}$, [Stefan] Popis $^{30}$, [Stefan] Gliszczyński ${ }^{31}$, [Tomasz] Zadęcki ${ }^{32}$.

27. Ks. Andrzej Łukasik - ur. 28 XI 1898 w Podlesiu. Święcenia kapłańskie przyjął 1 VI 1924. Od 30 XI 1938 był proboszczem parafii św. Teresy w Radomiu. Piastował tez urząd wicedziekana dekanatu Radom Północ (od 1953). Dwukrotnie więziony przez władze komunistyczne: od 14 VII 1950 do 28 VIII 1951 (pod zarzutem wspierania nielegalnej organizacji młodzieżowej "Orzeł Biały") oraz od 12 do 16 I 1967 (za odmowę prowadzenie księgi inwentarzowej). Zmarł 14 VII 1980 w Radomiu.KDS 74 (1981), s. 267-281; SBKDS, t. 2, s. 223-224; B. Stanaszek, Księża diecezji sandomierskiej więzieni przez władze komunistyczne po II wojnie światowej, Rzeszów 2008, s. 127-133. Inwigilowany przez funkcjonariuszy KP MO w Radomiu w ramach sprawy ewidencyjno-obserwacyjnej nr 1783 od 19 V 1956. AIPN Ki, Wykaz spraw ewidencyjno-obserwacyjnych prowadzonych na kler świecki i aktyw katolicki z diecezji sandomierskiej, Kielce, 17 XII 1959, k. 65-68 [dalej: Wykaz 1959].

28. Ks. Jan Chaczek - ur. 13 I 1904 w Wiśniowej. Święcenia kapłańskie przyjął 4 VI 1933. Od 1959 r. był proboszczem we Wrzosie. Zmarł 6 VI 1982 we Wrzosie. KDS 76 (1983), s. 235-236.

29. Ks. Stanisław Warchoł - ur. 26 XI 1904 w Gzowicach. Święcenia kapłańskie przyjął 20 I 1932. W l. 1945-1967 był proboszczem w Jarosławicach. Zmarł 3 X 1969 w Radomiu. KDS 63 (1970), s. 94-94.

30. Ks. Stefan Popis - ur. 18 V 1912 w Czarnolesie. Święcenia kapłańskie przyjął 28 VI 1936. Od 7 III 1955 był proboszczem parafii NSJ w Radomiu. Więziony przez władze komunistyczne w okresie od 26 XI do 3 XII 1966 za nieprowadzenie księgi inwentarzowej oraz niezłożenie sprawozdania z punktów katechetycznych. Zmarł 24 III 1996 w Radomiu. Kronika Diecezji Radomskiej [dalej: KDR] 5 (1996), s. 74-80; B. Stanaszek, Księża diecezji..., dz. cyt., s. 234-236.

31. Ks. Stefan Gliszczyński - ur. 26 VI 1897 w Strzemieszycach. Święcenia kapłańskie przyjął 7 V 1922. W l. 1948-1963 był proboszczem w Kowali. Zmarł 13 IV 1984 w Sandomierzu. KDS 78 (1985), s. 240-241. Inwigilowany przez funkcjonariuszy KP MO w Radomiu w ramach sprawy ewidencyjno-obserwacyjnej nr 1298 od 8 V 1956. AIPN Ki, Wykaz 1959.

32. Ks. Tomasz Zadęcki - ur. 13 XII 1895 w Głowaczowie. Święcenia kapłańskie przyjął 21 VII 1918. W 1. 1950-1963 był proboszczem w Pionkach. Zmarł 29 IX 1980 w Sandomierzu. KDS 76 (1983), s. 190-192. 
Opoczno:

[Piotr] Jaroszek ${ }^{33}$, [Wojciech?] Pedrycz ${ }^{34}$, [Marian] Gul ${ }^{35}$, [Marian] Misiak ${ }^{36}$, [Stanisław] Ciejka ${ }^{37}$, [Tadeusz] Podkowa ${ }^{38}$.

33. Ks. Piotr Jaroszek - ur. 12 VII 1905 w Jedlni. Święcenia kapłańskie przyjął 14 XII 1930. Od 6 XII 1954 był proboszczem i dziekanem w Opocznie. Zaangażowany w tzw. ruch księży patriotów. Zmarł 18 IX 1990 w Opocznie. KDS 83 (1990), s. 279281; SBKDS, t. 2, s. 37-38; B. Stanaszek, Diecezja sandomierska w powojennej rzeczywistości politycznej w latach 1945-1967, t. 1, Problematyka personalno-organizacyjna, Sandomierz 2006, s. 230-231. Inwigilowany przez funkcjonariuszy KP MO w Opocznie w ramach sprawy ewidencyjno-obserwacyjnej nr 1870 od 1956. AIPN Ki, Wykaz 1959.

34. W l. 60. w dekanacie opoczyńskim nie pracował żaden kapłan o nazwisku Pedrycz. Można przypuszczać, iż omyłkowo funkcjonariusze SB wpisali nazwisko duchownego, który w tym czasie (1951-1972) posługiwał w powiecie włoszczowskim, w parafii Konieczno - ks. Wojciech Pedrycz. Choć parafia ta znajdowała się w województwie kieleckim, podobnie jak dekanat opoczyński, to jednak w administracji kościelnej przynależała ona do diecezji kieleckiej. Duchowny ten podczas głoszonych kazań poruszał tematy, które przez ówcześnie rządzących były kwalifikowane jako „wrogie". R. Gryz, Państwo a Kościół w Polsce 1945-1956 na przykładzie województwa kieleckiego, Kraków 1999, s. 336.

35. Ks. Marian Gul - ur. 1 II 1896 w Pińczowie. Święcenia kapłańskie przyjął 7 V 1922. Od 8 IV 1945 był proboszczem w Sławnie. Zmarł 14 VII 1967 w Łodzi. KDS 60 (1967), s. 214-215; SBKDS, t. 1, s. 270-271. Inwigilowany przez funkcjonariuszy KP MO w Opocznie w ramach sprawy ewidencyjno-obserwacyjnej nr 350. AIPN Ki, Wykaz 1959.

36. Ks. Marian Misiak - ur. 3 VIII 1902 w Koprzywnicy. Święcenia kapłańskie przyjął 27 V 1928. W l. 1957-1965 był proboszczem w Petrykozach. Zmarł 6 XII 1988 w Krakowie. KDS 8 (1990), s. 34-35. Inwigilowany przez funkcjonariuszy KP MO w Opocznie w ramach sprawy ewidencyjno-obserwacyjnej nr 1906 od 22 X 1958. AIPN Ki, Wykaz 1959.

37. Ks. Stanisław Ciejka - ur. 30 X 1929 w Woli Zdakowskiej. Święcenia kapłańskie przyjął 30 V 1954. W 1. 1956-1964 był wikariuszem w Opocznie. Zmarł 26 VI 2007. w Gawłuszowicach. KDR 17 (2008), s. 572-573. Inwigilowany przez funkcjonariuszy KP MO w Opocznie w ramach sprawy ewidencyjno-obserwacyjnej nr 1907 od 19 X 1958. AIPN Ki, Wykaz 1959.

38. Ks. Tadeusz Podkowa - ur. 21 X 1926 w Rajcu Szlacheckim. Święcenia kapłańskie przyjął 10 VI 1951. W l. 1959-1962 był proboszczem w Zajączkowie. Dwukrotnie więziony przez władze komunistyczne: od 16 IX do 20 X 1958 (za buntowanie ludności przeciwko akcji dekrucyfikacyjnej) oraz od stycznia do 24 II 1960 (kontynuacja zasądzonej kary). Zmarł 12 II 1998 w Radomiu. KDR 8 (1999), s. 233-236; B. Stanaszek, Księża diecezji..., dz. cyt., s. 179-184. Inwigilowany przez funkcjonariuszy KP MO w Opocznie w ramach sprawy ewidencyjno-obserwacyjnej nr 2047 od 17 VII 1959. AIPN Ki, Wykaz 1959 . 
Końskie:

[Józef] Granat ${ }^{39}$, [Wacław] Ośka ${ }^{40}$, [Kazimierz] Pelc ${ }^{41}$, [Piotr] Figurskie ${ }^{42}$.

Skarżysko:

[o. Bogumił] Talarek ${ }^{43}$, [o. Augustyn] Kilian ${ }^{44}$, [Antoni] Boratyński ${ }^{45}$. e. oryginale błędnie wpisano

Figarski.

39. Ks. Józef Granat - ur. 18 XII 1908 w Drzenkowicach. Święcenia kapłańskie przyjął 28 VI 1936. W l. 1960-1963 był wikariuszem parafii Końskie, a następnie jej rezydentem. Zmarł 1 X 1990 w Końskich. KDS 84 (1991), s. 183-189; SBKDS, t. 1, s. 256. Inwigilowany przez funkcjonariuszy KP MO w Końskich w ramach sprawy ewidencyjno-obserwacyjnej nr 1908 od 1955. AIPN Ki, Wykaz 1959.

40. Ks. Wacław Ośka - ur. 30 IV 1901 w Ksawerowie Starym. Święcenia kapłańskie przyjął 24 VIII 1924. W 1. 1938-1966 był proboszczem w Pilczycy. Zmarł 9 VIII 1970 w Warszawie. KDS 63 (1970), s. 259-260.

41. Ks. Kazimierz Pelc - ur. 20 I 1907 w Siąszycach. Święcenia kapłańskie przyjął 29 VI 1934. W l. 1956-1964 był proboszczem w Odrowążu. Zmarł 29 VII 1986 w Ostrowcu Świętokrzyskim. KDS 80 (1987), s. 174-185. Inwigilowany przez funkcjonariuszy KP MO w Końskich w ramach sprawy ewidencyjno-obserwacyjnej nr 1612 od 28 IV 1956. AIPN Ki, Wykaz 1959.

42. Ks. Piotr Figurski - ur. 4 IX 1892 w Sieciechowie-Mieście. Święcenia kapłańskie przyjął 30 VII 1916. Od 27 IV 1960 był proboszczem w Fałkowie oraz wicedziekanem dekanatu przedborskiego. Zmarł 6 I 1974 w Fałkowie. KDS 67 (1974), s. 95-65; SBKDS, t. 1, s. 195-196.

43. O. Bogumił Talarek - franciszkanin konwentualny, ur. 6 III 1914. Święcenia kapłańskie przyjął w 1940. Od 1956 był administratorem parafii Niepokalanego Poczęcia NMP w Skarżysku Kamiennej. Zmarł 11 III 2006 w Sławnie. Rocznik Diecezji Sandomierskiej [dalej: RDS] 1960, s. 170.

44. O. Augustyn Kilian - redemptorysta, ur. w 1924. Święcenia kapłańskie przyjął w 1948. Od 1959 był duszpasterzem przy kaplicy rektoralnej na os. Bór w Skarżysku Kamiennej.

45. Ks. Antoni Cebula (vel. Boratyński) - ur. 24 XI 1905 w Dąbiu. Święcenia kapłańskie przyjął 29 VI 1934. W 1. 1952-1963 był proboszczem parafii św. Józefa w Skarżysku Kamiennej. Zmarł 25 IV 1980 w Opocznie. KDS 74 (1981), s. 91-95; SBKDS, t. 1, s. 100. Inwigilowany przez funkcjonariuszy KP MO w Skarżysku Kamiennej w ramach sprawy ewidencyjno-obserwacyjnej nr 1877. AIPN Ki, Wykaz 1959. 


\section{Starachowice:}

[Stanisław] Maliński ${ }^{46}$, [Marian] Piwowarczyk ${ }^{47}$, [Zygmunt] Lewiński ${ }^{48}$.

46. Ks. Stanisław Maliński - ur. 16 IX 1912 w Jaraczewie. Święcenia kapłańskie przyjął 6 VI 1937. W l. 1955-1971 zarządza parafią Skarżysko Kościelne (jako wikariusz pomocnik, wikariusza zarządca i proboszcz - od 1964 r.). Zmarł 7 XII 1976 w Ostrowcu Świętokrzyskim. KDS 71 (1978), s. 45-47. Inwigilowany przez funkcjonariuszy KP MO w Starachowicach w ramach sprawy ewidencyjno-obserwacyjnej nr 1896 od 25 IX 1958. AIPN Ki, Wykaz 1959.

47. Ks. Marian Piwowarczyk - ur. 16 VII 1907 w Komaszynie. Święcenia kapłańskie otrzymał 19 II 1933. W 1. 1957-1966 był proboszczem w Krynkach. KDS 74 (1981), s. $239-240$.

48. Ks. Zygmunt Lewiński - ur. 5 VI 1924 w Sobolewie. Święcenia kapłańskie przyjął 25 V 1952. W 1. 1952-1961 był wikariuszem parafii św. Trójcy w Starachowicach. Zmarł 7 VII 2001 w Jedlni Letnisko. KDR 11 (2002), s. 135-136. 
Ostrowiec:

[Jan] Bania ${ }^{49}$, [Marcin] Popiel ${ }^{50}$, [Władysław] Rączkiewicz ${ }^{51}$, [Jan] Rutkowski $^{52}$, [Antoni] Gołębskif ${ }^{53}$, [Leon] Janicki ${ }^{54}$ i [Stanisław] Dudziński ${ }^{55}$.

f. w oryginale błędnie wpisa no Gołąbski.

49. Ks. Jan Bania - ur. 21 XII 1912 w Solcu nad Wisłą. Święcenia kapłańskie przyjął 11 VI 1939. W 1. 1958-1963 był proboszczem parafii NMP w Ostrowcu Świętokrzyskim. Zmarł 16 XI 1987 w Garbatce Letnisko. KDS 82 (1989), s. 138-139; SBKDS, t. 1, s. 32-33. Inwigilowany przez funkcjonariuszy KP MO w Ostrowcu Świętokrzyskim w ramach sprawy ewidencyjno-obserwacyjnej nr 1977 od 29 XII 1955. AIPN Ki, Wykaz 1959; AIPN Ki, sygn. 015/819, Notatka służbowa, Kielce, 15 XI 1962, k. 59-6o.

50. Ks. Marcin Popiel - ur. 21 III 1904 w Kurozwękach. Święcenia kapłańskie przyjął 16 XII 1945. Od 10 I 1946 był wikariuszem, a następnie proboszczem w Szewnie. Więziony przez władze komunistyczne w okresie od 13 do 23 VII 1964, za odprawienie mszy świętej odpustowej w Wierzbicy (szerz. zob. S. Kowalik, Konflikt wyznaniowy w Wierzbicy. Niezależna parafia w polityce władz PRL (1962-1977), Lublin 2012). KDS 85 (1992), s. 109-119; B. Stanaszek, Księża diecezji.., dz. cyt., s. 210-215. Inwigilowany przez funkcjonariuszy KP MO w Ostrowcu Świętokrzyskim w ramach sprawy ewidencyjno-obserwacyjnej nr 1905 od 15 X 1958. AIPN Ki, Wykaz 1959; AIPN Ki, sygn. 015/819, Notatka służbowa, Kielce, 15 XI 1962, k. 60-61.

51. Ks. Władysław Rączkiewicz - ur. 23 VIII 1914 w Chobrzanach. Święcenia kapłańskie przyjął 11 VI 1939. W l. 1956-1967 był proboszczem w Modliborzycach. Zmarł 19 VI 1994 w Sandomierzu. KDS 87 (1994), s. 374-379. Inwigilowany przez funkcjonariuszy KP MO w Ostrowcu Świętokrzyskim w ramach sprawy ewidencyjno-obserwacyjnej nr 1864 od 24 VI 1958. AIPN Ki, Wykaz 1959; AIPN Ki, sygn. 015/819, Notatka służbowa, Kielce, 15 XI 1962, k. 61.

52. Ks. Jan Rutkowski - ur. 24 XII 1903 w Wąchocku. Święcenia kapłańskie przyjął 25 V 1929. Od 1949 r. był proboszczem parafii NSJ w Ostrowcu Świętokrzyskim. Zmarł 12 XII 1976 w Ostrowcu Świętokrzyskim. KDS 72 (1979), s. 45-46. Inwigilowany przez funkcjonariuszy KP MO w Ostrowcu Świętokrzyskim w ramach sprawy ewidencyjno-obserwacyjnej nr 1684 od 7 V 1955, a następnie sprawy grupowej (wraz z ks. Bolesławem Sałatą) ewidencyjno-obserwacyjnej nr 1257 od 11 XI 1960. AIPN Ki, Wykaz 1959; AIPN Ki, sygn. 015/819, Notatka służbowa, Kielce, 15 XI 1962, k. 60.

53. Ks. Antoni Gołębski - ur. 14 VI 1915 w Baszowicach. Święcenia kapłańskie przyjął w 1940. W 1. 1959-1963 był proboszczem w Bodzechowie. RDS 1960, s. 68. Inwigilowany przez funkcjonariuszy KP MO w Ostrowcu Świętokrzyskim w ramach sprawy ewidencyjno-obserwacyjnej nr 1237 od 2 II 1962. AIPN Ki, sygn. 015/819, Notatka służbowa, Kielce, 15 XI 1962, k. 59.

54. Ks. Leon Janicki - ur. 7 IV 1905 w Usarkowie. Święcenia kapłańskie przyjął 27 V 1928. Od 20 VIII 1958 był proboszczem w Iwaniskach oraz wicedziekanem dekanatu opatowskiego (od 9 XI 1960). Zmarł 9 IV 1972 w Ostrowcu Świętokrzyskim. KDS 65 (1972), s. 119-120; SBKDS, t. 2, s. 28-29. Inwigilowany przez funkcjonariuszy KP MO w Ostrowcu Świętokrzyskim w ramach sprawy grupowej (wraz z ks. Stanisławem Skibą) ewidencyjno-obserwacyjnej nr 1238 od 9 III 1961. AIPN Ki, sygn. 015/819, Notatka służbowa, Kielce, 15 XI 1962, k. 62.

55. Ks. Stanisław Dudziński - ur. 17 IX 1897 w Dobieszowicach. Święcenia kapłańskie przyjął 26 V 1923. W 1. 1938-1962 był proboszczem w Ćmielowie oraz wicedziekanem dekanatu kunowskiego (od 14 IX 1955). Zmarł 10 II 1976 w Białaczowie. KDS 69 (1976), s. $68-69$; SBKDS, t. 1, s. 173-174. 


\section{Sandomierz:}

[bp Jan Kanty] Lorek ${ }^{56}$, [bp Piotr] Gołębiowskii ${ }^{57}$ [bp Walenty] Wójcik ${ }^{58}$, [Lucjan] Wojciechowski ${ }^{59}$, [Jan] Koceniak ${ }^{60}$, [Bolesław] Skwarliński ${ }^{61}$, [Jan] Wiącek $^{62}$ i [Stanisław] Wróbel ${ }^{63}$.

56. Bp Jan Kanty Lorek - ur. 20 X 1886 w Błażejowicach. Wstąpił do Zgromadzenia Księży Misjonarzy św. Wincentego à Paulo w Krakowie. Święcenia kapłańskie przyjął 2 VII 1911. W 1936 r. mianowany administratorem apostolskim diecezji sandomierskiej. 7 VI 1936 przyjął sakrę biskupią. Zmarł 4 I 1967 w Sandomierzu. Inwigilowany przez UB w ramach sprawy o krypt. „Okoń" (1. 40. i 50. - agenturalnego rozpracowania, później ewidencyjno-obserwacyjnej o numerze 1927). B. Stanaszek, Usunać Biskupa! Władze PRL wobec Ordynariusza Diecezji Sandomierskiej Jana Kantego Lorka, Sandomierz 2004; AIPN Ki, sygn. 015/824, t. 5, Plan operacyjnych przedsięwzięć do sprawy ewidencyjno-obserwacyjnej nr 1927 kryptonim "Okoń", Kielce, 4 VII 1959, k. 150-155.

57. Bp Piotr Gołębiowski - ur. 10 VI 1902 w Jedlińsku. Święcenia kapłańskie przyjął 12 X 1924. 3 VI 1957 otrzymał nominację na biskupa pomocniczego diecezji sandomierskiej. Sakrę biskupią przyjął 28 VII 1957. Od 26 II 1968 był administratorem apostolskim wspomnianej diecezji. Zmarł 2 XI 1980 w Nałęczowie. Trwa jego proces beatyfikacyjny. Inwigilowany przez funkcjonariuszy Grupy V Wydziału III WUBP w Kielcach w ramach grupowej (ks. Lucjan Wojciechowski, ks. Władysław Korpikiewicz, ks. Tadeusz Kęsik) sprawy ewidencyjno-obserwacyjnej nr 1786 o krypt. "Burzyciele" od 20 II 1958 B. Stanaszek, „Wrogo ustosunkowany do naszego państwa". Biskup Piotr Gołębiowski w dokumentach komunistycznej bezpieki $i$ władz wyznaniowych, Sandomierz 2006; A. Warso, Represje paszportowe wobec biskupa Piotra Gołębiowskiego, "Studia Sandomierskie" 9 (2002), s. 485-499; AIPN Ki, sygn. 015/824, t. 5, Plan operacyjnych przedsięwzięć w sprawie ewidencyjno-obserwacyjnej na grupę nr 1786 krypt. „Burzyciele”, Kielce, 1 VII 1959, k. 156-161.

58. Bp Walenty Wójcik - ur. 9 IX 1914 w Byszówce. Święcenia kapłańskie przyjął 11. VI 1939. Od 1959 pracował na Wydziale Prawa Kanonicznego KUL. 26 X 1960 mianowany biskupem pomocniczym diecezji sandomierskiej, sakrę biskupią przyjął 2. II 1961. Zmarł 22 XI 1990. A. Kończak, Walenty Wójcik - biskup i profesor, „Studia Sandomierskie" 6 (1990-1996), s. 357-377.

59. Ks. Lucjan Wojciechowski - ur. 30 X 1916 w Połańcu. Święcenia kapłańskie przyjął 9 VI 1940. Od 1952 był profesorem Seminarium Duchownego w Sandomierzu. Zmarł 10 II 2003 w Radomiu. KDR 15 (2006), s. 143-149. Inwigilowany przez funkcjonariuszy Grupy V Wydziału III WUBP w Kielcach w ramach grupowej (bp. Piotr Gołębiewski, ks. Władysław Korpikiewicz, ks. Tadeusz Kęsik) sprawy ewidencyjno-obserwacyjnej nr 1786 o krypt. „Burzyciele” od 20 II 1958. AIPN Ki, sygn. 015/824, t. 5, Plan operacyjnych przedsięwzięć w sprawie ewidencyjno-obserwacyjnej na grupę nr 1786 krypt. „Burzyciele", Kielce, 1 VII 1959, k. 156-161.

6o. Ks. Jan Koceniak - ur. 3 II 1913 w Młodochowie. Święcenia kapłańskie przyjął 11 VI 1939. Doktor teologii. Od 15 IX 1951 profesor Seminarium Duchownego w Sandomierzu. Pracował w sandomierskiej kurii oraz sądzie biskupim. Zmarł 19 VII 1984 w Sandomierzu. KDS 77 (1984), s. 265; KDS 78 (1985), s. 177-180; SBKDS, t. 2, s. 99-100; W. Wójcik, Ks. Jan Koceniak (1913-1984), "Studia Sandomierskie" 5 (1985), s. 492-505.

61. Ks. Bolesław Skwarliński - ur. 25 VIII 1915 w Czerwonej Górze. Święcenia kapłańskie przyjął 11 VI 1938. Od 1959 był rektorem kościoła św. Ducha w Sandomierzu i profesorem seminarium duchownego. Zmarł 10 VIII 1967 w Sandomierzu. KDS 61 (1968), s. $238-239$. 


\section{Kozienice:}

[Stanisław] Sikorski ${ }^{64}$, [Jan] Chałupczak ${ }^{65}$, [Józef] Kuropieska ${ }^{66}$.

Zwoleń:

[Leon] Figarski ${ }^{67}$, [Aleksander] Szczęsny ${ }^{68}$.

62. Ks. Jan Wiącek - ur. 24 VI 1900 w Trzciance. Święcenia kapłańskie przyjął 29 V 1927. Od 1954 r. był proboszczem w Koprzywnicy. Zmarł 4 V 1973 w Koprzywnicy. KDS 66 (1973), s. 259-261. Inwigilowany przez funkcjonariuszy KP MO w Sandomierzu w ramach sprawy ewidencyjno-obserwacyjnej nr 66 od 12 V 1955. AIPN Ki, Wykaz 1959.

63. Ks. Stanisław Wróbel - ur. 26 IV 1908 w Zdanowie. Święcenia kapłańskie przyjął 27 V 1933. Od 1956 r. był proboszczem w Klimontowie. Zmarł 17 V 1987 w Sandomierzu. KDS 82 (1989), s. 182-188. Inwigilowany przez funkcjonariuszy KP MO w Sandomierzu w ramach sprawy ewidencyjno-obserwacyjnej nr 2013 od 23 V 1959. AIPN Ki, Wykaz 1959.

64. Ks. Stanisław Sikorski - ur. 23 IV 1910 w Kazimierzy Wielkiej. Święcenia kapłańskie przyjął 29 VI 1934. W 1. 1951-1971 był proboszczem w Głowaczowie. Zmarł 12 XII 1993 w Radomiu. KDR 14 (2005), s. 335-338. Inwigilowany przez funkcjonariuszy KP MO w Kozienicach w ramach sprawy ewidencyjno-obserwacyjnej nr 67 od $13 \mathrm{~V}$ 1955. AIPN Ki, Wykaz 1959.

65. Ks. Jan Chałupczak - ur. 3 XI 1899 w Przezwodach. Święcenia kapłańskie przyjął 29 V 1927. Od 7 X 1950 był proboszczem w Brzeźnicy. Zmarł 11 II 1968 w Brzeźnicy. KDS 62 (1969), s. 165; SBKDS, t. 1, s. 103. Inwigilowany przez funkcjonariuszy KP MO w Kozienicach w ramach sprawy ewidencyjno-obserwacyjnej nr 1320 od 30 V 1956. AIPN Ki, Wykaz 1959.

66. Ks. Józef Kuropieska - ur. 8 II 1904 w Słupnicy. Święcenia kapłańskie przyjął 25 V 1929. Od 23 IX 1942 zarządzał parafią Garbatka (jako administrator, a następnie proboszcz). W 1959 został wicedziekanem dekanatu pionkowskiego. Więziony przez władze komunistyczne w okresie od 10 do 16 IX 1966 za nieprowadzenie księgi inwentarzowej. Zmarł 26 IX 1971 w Warszawie. KDS 64 (1971), s. 283-285; SBKDS, t. 2, s. 178-179; B. Stanaszek, Księża diecezji..., dz. cyt., s. 231-232. Inwigilowany przez funkcjonariuszy KP MO w Kozienicach w ramach sprawy ewidencyjno-obserwacyjnej nr 674 od 14 VI 1955. AIPN Ki, Wykaz 1959.

67. Ks. Leon Figarski - ur. 10 IV 1892 w Woli Lipienickiej. Święcenia kapłańskie przyjął 27 IX 1914. Od 1 X 1951 był proboszczem w Kazanowie Iłżeckim, a w l. 1961-1963 dziekanem dekanatu iłżeckiego. Zmarł 23 V 1982 w Kazanowie Iłżeckim. KDS 76 (1983), s. 140-141; SBKDS, t. 1, s. 194-195. Inwigilowany przez funkcjonariuszy KP MO w Zwoleniu w ramach sprawy ewidencyjno-obserwacyjnej nr 1884 od 26 VIII 1958. AIPN Ki, Wykaz 1959.

68. Ks. Aleksander Szczęsny - ur. 21 III 1915 w Aleksandrowie Kujawskim. Święcenia kapłańskie przyjął 11 VI 1939. Od 1960 r. był proboszczem w Tczowie. Zmarł 24 XII 1969 w Radomiu. KDS 63 (1970), s. 143. Inwigilowany przez funkcjonariuszy KP MO w Końskich w ramach sprawy ewidencyjno-obserwacyjnej nr 1922 od 12 XI 1958. AIPN Ki, Wykaz 1959. 
w oryginale błędnie wpisano Sorbian.

\author{
Białobrzegi: \\ [Józef] Dziadowicz ${ }^{69}$, [Józef] Barański ${ }^{70}$, [Jan] Król ${ }^{71}$.
}

Przysucha:

[Stefan] Sułecki ${ }^{72}$, [Franciszek] Sorbjan ${ }^{973}$, [Józef] Śliwak ${ }^{74}$.

\author{
Szydłowiec: \\ [Józef] Janicki ${ }^{75}$, [Franciszek] Chlebny ${ }^{76}$, [Bonawentura] Stachura ${ }^{77}$.
}

69. Ks. Józef Dziadowicz - ur. 14 III 1917 w Bogorii. Święcenia kapłańskie przyjął w 1941. W l. 1953-1962 był proboszczem w Białobrzegach i dziekanem dekanatu jedlińskiego. RDS 1960, s. 42. Inwigilowany przez funkcjonariuszy KP MO w Białobrzegach w ramach sprawy ewidencyjno-obserwacyjnej nr 1915 od 30 X 1958. AIPN Ki, Wykaz 1959.

70. Ks. Józef Barański - ur. 24 I 1917 w Topolicach. Święcenia kapłańskie przyjął 10 V 1941. W l. 1957-1973 był proboszczem parafii Gózd. Zmarł 22 X 2003 w Końskich. KDR 15 (2006), s. 307-310. Inwigilowany przez funkcjonariuszy KP MO w Białobrzegach w ramach sprawy ewidencyjno-obserwacyjnej nr 1767 od 1955. AIPN Ki, Wykaz 1959.

71. Ks. Jan Król - ur. 24 VI 1915 w Piórkowie. Święcenia kapłańskie przyjął 10 V 1941. W l. 1947-1971 był proboszczem parafii Radzanów. Zmarł 7 III 1989 w Górze Puławskiej. Inwigilowany przez funkcjonariuszy KP MO w Białobrzegach w ramach sprawy ewidencyjno-obserwacyjnej nr 1300 od 10 V 1956. AIPN Ki, Wykaz 1959.

72. Ks. Stefan Sułecki - ur. 9 II 1912 w Taczowie. Święcenia kapłańskie przyjął 6 VI 1937. W 1. 1960-1976 był proboszczem w Skrzynnie. Zmarł 30 IX 1981 w Radomiu. KDS 75 (1982), s. 179-183. Inwigilowany przez funkcjonariuszy KP MO w Radomiu w ramach sprawy ewidencyjno-obserwacyjnej nr 1033 od 2 VI 1956. AIPN Ki, Wykaz 1959.

73. Ks. Franciszek Sorbjan - ur. 17 I 1909 w Niekłaniu Małym. Święcenia kapłańskie przyjął 4 VI 1933. W l. 1957-1985 był kapelanem Sióstr Służek NMP Niepokalanej w Mariówce. Zmarł 9 XII 1985 w Skarżysku Kamiennej. KDS 79 (1986), s. 235-239.

74. Ks. Józef Śliwak - ur. 4 III 1919 w Bawarii. Święcenia kapłańskie przyjął 7 V 1944. W l. 1958-1971 przebywał w parafii Chlewiska, gdzie rezydował przy kościele w Rzucowie. Zmarł 31 VII 1984 w Opocznie. 79 (1984), s. 275-278. Inwigilowany przez funkcjonariuszy KP MO w Przysusze w ramach sprawy ewidencyjno-obserwacyjnej nr 1944 od 1 XII 1958. AIPN Ki, Wykaz 1959.

75. Ks. Józef Janicki - ur. 29 VII 1922 w Tczowie Średnim. Święcenia kapłańskie przyjął 10 VI 1951. Od 6 IV 1957 był administratorem w Orońsku, a następnie proboszczem tej parafii. Zmarł 13 I 1987 w Sandomierzu. KDS 82 (1989), s. 47-50; SBKDS, t. 2, s. 27-28. Inwigilowany przez funkcjonariuszy KP MO w Szydłowcu w ramach sprawy ewidencyjno-obserwacyjnej nr 2051 od 18 VIII 1959. AIPN Ki, Wykaz 1959.

76. Ks. Franciszek Chlebny - ur. 7 XII 1898 w Denkówku. Święcenia kapłańskie przyjął 31 V 1925. W l. 1960-1962 był proboszczem w Jastrzębiu. Zmarł 19 II 1967 w Ćmielowie. KDS 60 (1967), s. 212-213; SBKDS, t. 1, s. 106-107.

77. Ks. Bonawentura Stachura - ur. 2 IX 1906 w Wyszmontowie. Święcenia kapłańskie przyjął 19 II 1933. Od 1947 r. zarządzał parafią w Mirowie (jako wikariusz ekonom i proboszcz). Zmarł 12 II 1991 w Mirowie. KDS 84 (1991), s. 273-274. 
Staszów:

[Wacław] Nagrodkiewicz ${ }^{\text {h78 }}$, [Antoni] Zmysłowski ${ }^{79}$.

Wspomniani ${ }^{i}$ wyżej księża rekrutują się z grupy popleczników i zwolenników polityki reakcyjnej bpa [Jana Kantego] Lorka i stanowią transmisję w przekazywaniu i realizacji wszelkich zarządzeń kurialnych w terenie. Ostatnio zajmują oni najbardziej "sztywne" stanowisko w utrzymaniu i organizowaniu nowych punktów katechetycznych, niepodporządkowania się Zarządzeniu Ministra Oświaty oraz nie wykonywanie innych zarządzeń i ustaw państwowych. Najbardziej oporni są w płaceniu podatków, natomiast na swych parafiach prowadzą najaktywniejszą działalność duszpasterską. Obok tego oddziaływają na innych szantażem i różnego rodzaju denuncjacjami i zastraszeniem utrzymać w posłuszeństwie i jedności z biskupami.

Wroga działalność kleru parafialnego na terenie diecezji sandomierskiej prowadzona jest w następujących kierunkach:

- Zgodnie z hasłem V-go roku nowenny "Rodzina bogiem [sic!] silna"80 oraz zaleceń Episkopatu i kurii diecezjalnej, uaktywnienia pracy duszpasterskiej wśród rodzin, w celu budzenia życia religijnego, tworzenia tzw. "Laikatu" i nawracania „wątpiących" i zaniedbujących się rodzin w praktykach religijnych. W tym celu prowadzone są specjalne rekolekcje i nauki stanowe, misje i akcje miłosierdzia, tworzone kółka różańcowe itp. ${ }^{j}$ mające na celu szerzenie fanatyzmu religijnego czyli tzw. „odkomunizowania" społeczeństwa na 1000-lecie "Chrztu Polski".

- Prowadzenie totalnej akcji o młodzież szkolną i pozaszkolną. Organizowanie jej w kółkach ministrantów, kółkach bieli, chórów i innych stowarzyszeń i organizacji przykościelnych, dla której prowadzone są specjalne nauki stanowe na poszczególnych parafiach oraz rekolekcje zamknięte w Sandomierzu. Dla kawalerów i panien oraz młodych małżeństw h. w oryginale błędnie wpisano Nadgrodkiewicz.

i. w oryginale: wspomnieni.

j. w oryginale: i.t.p.

78. Ks. Wacław Nagrodkiewicz - ur. 27 III 1904 w Kolonii Gulew. Święcenia kapłańskie przyjął 25 V 1929. W l. 1956-1965 był proboszczem i dziekanem w Staszowie. Zmarł 20 VI 1992 w Iłży. KDR 13 (2004), s. 531-534.

79. Ks. Antoni Zmysłowski - ur. 28 V 1900 w Gowarczowie. Święcenia kapłańskie przyjął 25 V 1927. W l. 1943-1965 był proboszczem w Kurozwękach. Zmarł 25 IV 1983 KDS 78 (1985), s. 91-94.

80. Zob. B. Noszczak, Przygotowania do Millenium Chrztu Polski i Tysiaclecia Państwa Polskiego (1965-1965), w: Millenium czy Tysiaclecie, red. B. Noszczak, Radom [2006], s. 11-38; Z. Zieliński, Duszpasterski aspekt obchodów Tysiąclecia Chrztu Polski, w: Kościół i Prymas Stefan Wyszyński 1956-1966, red. A. Dziurok, W. Wysocki, Katowice-Kraków 2008, s. 77-85. 
prowadzone są nauki i rekolekcje z dziedziny seksuologii i współżycia małżeńskiego w celu „uświadomienia" ich i nakłonienia do nieprzestrzegania Ustawy o zapobieganiu ciąży ${ }^{81}$.

- Prowadzenie totalnej walki o nauczanie religii w punktach katechetycznych dzieci i młodzieży szkolnej, utrzymania stanu punktów katechetycznych z ubiegłego roku, bądź organizowania nowych, przy czym nieprzestrzegania Zarządzenia Ministra Oświaty z dnia 19.VIII.1961 r. dot[yczącego] punktów katechetycznych ${ }^{82}$.

- Bojkotowania zarządzeń i przepisów Ministra Finansów przez niepłacenie regularne podatków parafialnych i osobistych w wysokości wymierzonej przez poszczególne Wydz[iałów] Fin[ansowych] PPRN, odwoływania się w tych sprawach do władz wyższych i przeciągania w nieskończoność spłacanie podatków, aż do ich obniżenia lub umorzenia przez te władze.

- Prowadzenia szerokiej akcji na rzecz budownictwa sakralnego i parafialnego, remontów i renowacji, przy czym nie przestrzega się obowiązujących zarządzeń władz państwowych. Należy tu nadmienić, że organizowanym pielgrzymkom kler nadał nową formę - indywidualnych wyjazdów do obranych miejscowości - aby przez to uniknąć odpowiedzialności i ominąć obowiązujące w tej mierze przepisy władz państwowych.

81. Ustawa PRL z dnia 27 kwietnia 1956 r. o warunkach dopuszczalności przerywania ciąży, zezwalała m. in. na aborcję w przypadku „trudnych warunków życiowych kobiety ciężarnej" (Dz.U. PRL z 1956 Nr 12, poz 61). M. Truszczyński, PRL, a Kościół rzymskokatolicki. Mechanizmy władzy, sposoby represji. Studium wybranych przypadków z lat 1944-1989, Szulborze Wielkie 2010, s. 124. Zob. G. Miernik, Wokół ustawy aborcyjnej z 1956 r., w: Zdrowie i choroba. Wpływ jakości życia na kulturę w Europie środkowej, red. A. Barciak, Katowice-Zabrze 2013, s. 348-375.

82. Zarządzenie Ministra Oświaty z 19 sierpnia 1961 r. w sprawie prowadzenia punktów katechetycznych (Dz.Urz. MInistra Oświaty z $1961 \mathrm{Nr}$ 10, poz. 124). Nauczanie religii mogło odbywać się w tych miejscach, po spełnieniu określonych wymogów: zarejestrowaniu punktu w inspektoracie oświaty oraz zapewnieniu odpowiednich warunków higieniczno-sanitarnych. Ponadto katechizację mogły prowadzić jedynie osoby duchowne lub świeckie posiadające zgodę władz oświatowych. Kontrolę nad prawidłowym funkcjonowaniem punktów katechetycznych miał sprawować inspektor oświaty. Jeżeli administrator parafii spełnił wszystkie wyżej wymienione warunki mógł otrzymać 1 tys. zł wynagrodzenia. Pieniądze te miały pokryć wszystkie koszty funkcjonowania punktu, dlatego duchowni nie mogli pobierać jakichkolwiek opłat od rodziców dzieci uczęszczających na katechizację. Dokument ten obowiązywał do 23 X 1981, kiedy to uznano katechizację za sprawę wewnętrzną Kościoła katolickiego. Nadzór władz oświatowych nad katechizacją został zaniechany. M. Pietrzak, Prawo wyznaniowe, Warszawa 1999, s. 194-196; H. Konopka, Religia w szkołach Polski Ludowej. Sprawa nauczania religii w polityce państwa (1944-1961), Białystok 1997, s. 284-285. 
- Przy każdej parafii tworzenie i mobilizowanie tzw. "Krucjaty Wstrzemięźliwości", "Akcji Miłosierdzia" i aktywu katolickiego do wykonania zadań stojących przed klerem w okresie „wielkiej nowenny na 1000-lecie „Chrztu ${ }^{j}$ Polski.

Z dotychczasowej analizy i oceny prowadzonych spraw wynika, że w zasadzie do każdego figuranta tych spraw jest w większości zapewniony dopływ informacji i działalność każdego z nich na ogół na bieżąco jest znana. W niektórych sprawach, jak: [Stanisława] Głąbińskiego ${ }^{83}$, [Władysława] Rączkiewicza i [Jana] Rutkowskiego w Ostrowcu, [Bonawentury] Stachury i [Józefa] Janickiego w Szydłowcu, [Jana] Wiącka i [Stefana] Wróbla w Sandomierzu, [Józefa] Granata i [Kazimierza] Pelca w Końskich, [Mariana] Gula, [Piotra] Jaroszka i [Mariana] Misiaka w Opocznie, [Andrzeja] Łukasika, [Jana] Chaczka, [Tomasza] Zadęckiego i [Mariana] Nowakowskiego ${ }^{84}$ w Radomiu, [Stefana] Sułeckiego i [Józefa] Śliwaka w Przysusze, stosowane są przemyślane i skuteczne przedsięwzięcia operacyjne, które przyczyniają się do ${ }^{\mathrm{k}}$ pohamowania ${ }^{1}$ ich aktywnej działalności duszpasterskiej i neutralizacji. Niemniej jednak są również sprawy o słabym dopływie informacji, które ze względu na osobę i działalność figuranta wymagają większej niż dotychczas aktywnej obserwacji i zabezpieczenia systematycznego dopływu informacji. Do nich należą:

- sprawy na ks. [Leona] Figarskiego i ks. [Aleksandra] Szczęsnego w Zwoleniu,

- sprawa grupowa na księży: [Jana] Rutkowskiego, [Bolesława] Sałatę $^{85}$ i [Piotra] Karbowiaka ${ }^{86}$ w Ostrowcu,

- sprawa na ks. [Piotra] Jaroszka w Opocznie,

83. Ks. Stanisław Głąbiński - ur. 7 XI 1892 w Osówce. Święcenia kapłańskie przyjął 21 III 1915. W 1. 1940-1965 był proboszczem parafii Błotnica. Zmarł 6 IX 1965. KDS 58 (1965), s. 262-265.

84. Ks. Marian Nowakowski - ur. 17 IV 1903 w Poświętnem. Święcenia kapłańskie przyjął 31 V 1925. W l. 1939-1961 był proboszczem w Piotrowicach, a od 1961 r. dziekanem dekanatu radomskiego podmiejskiego. Zmarł 25 XII 1983. KDS 77 (1984), s. $276-283$.

85. Ks. Bolesław Sałata - ur. 13 X 1926 w Suchodółce. Święcenia kapłańskie przyjął 25 V 1952. W 1. 1954-1963 był wikariuszem parafii NSJ w Ostrowcu Świętokrzyskim. Zmarł 29 VIII 2011 w Sandomierzu. KDS 104 (2011), s. 969-974. Inwigilowany przez funkcjonariuszy KP MO w Ostrowcu Świętokrzyskim w ramach sprawy grupowej (wraz z ks. Janem Rutkowskim) ewidencyjno-obserwacyjnej nr 1257 od 11 XI 1960. AIPN Ki, sygn. 015/819, Notatka służbowa, Kielce, 15 XI 1962, k. 60.

86. Ks. Piotr Karbowiak - ur. 27 VI 1921 w Krzyżanowicach. Święcenia kapłańskie przyjął 22 V 1949. W l. 1958-1961 był wikariuszem parafii NSJ w Ostrowcu Świętokrzyskim. RDS 1960, s. 72.

Piotr Tylec, Inwigilacja duchowieństwa diecezji sandomierskiej...

k. wyraz dopisano ręcznie.

1. w oryginale: pochamowania. 
m. w oryginale: i.t.p.
- sprawa na ks. [Jana] Wiącka w Sandomierzu,

- sprawy na ks. [Józefa] Janickiego i ks. [Bonawenturę] Stachurę w Szydłowcu i inne.

W świetle wyżej omawianej sytuacji operacyjnej na tym odcinku praca operacyjna pójdzie w następującym kierunku:

- organizowanie nowych źródeł informacji dla operacyjnego umocnienia się oraz szerszego i wnikliwszego dotarcia do figurantów spraw, a zwłaszcza pozostających dotąd bez agentury, spośród kleru zajmującego stanowiska kierownicze na terenie diecezji wśród kleru dołowego, lub mogące je zająć w perspektywie, względnie spośród osób mających dostęp do kleru kurialnego, kanoników kapituł i dziekanów, a także mających dostęp do poufnych spraw, tajnych dokumentów, dotyczących aktualnych planów i zamierzeń kurii.

- rozeznać na bieżąco sytuację istniejącą pomiędzy księżmi kurialistami, a dołowym klerem w diecezji, ustalania tarć, intryg, nieporozumień, osobistych ambicji itp. ${ }^{\mathrm{m}} \mathrm{w}$ celu operacyjnego wykorzystania tych faktów, inspirowania i pogłębiania ich, oraz osłabiania w ten sposób spoistości i jedności kleru dołowego z biskupami.

- rozeznawania na bieżąco planów zamierzeń i przedsięwzięć kurii i zaleceń dla kleru dołowego na odcinku politycznym, społecznym, duszpasterskim, organizacyjnym, kadrowym, budów obiektów sakralnych oraz prac wśród młodzieży w celu wyciągania odpowiednich wniosków do pracy operacyjnej na tym odcinku i przeciwdziałania.

- rozeznawania prywatnego życia kleru parafialnego, otoczenia, trybu i sposobu życia, kontaktów, a szczególnie z aktywem katolickim jak: lekarze, adwokaci, nauczyciele, prywatna inicjatywa i urzędnicy w celu ich operacyjnego wykorzystania.

- W celu uaktywnienia obserwacji figurantów spraw na księży: [Piotra] Jaroszka z Opoczna, [Jana] Wiącka z Koprzywnicy, [Andrzeja] Łukasika z Radomia i [Leona] Figarskiego z Kazanowa przyjąć pod nadzór grupy V Wydz[iału] III-go te sprawy i udzielić w nich szczególnej pomocy, 
wykorzystując do tego celu t[ajnych] w[spółpracowników] "Grzegorz", "B-5", "Janaszkiewicz"87 i „Wąkop" ${ }^{88}$.

Obok tego wykorzystać aktywniej technikę operacyjną: "W"89 i „T"90.

St[arszy] Of[icer] Oper[acyjny] Wydz[iału] III-go

[podpis nieczytelny]

/Walaszczyk Jan kpt ${ }^{91} /$

Odbito w 1 egz.

Opr[acoawał] W[alaszczyk] J[an]/MJ

Źródło: AIPN Ki, sygn. o15/824, t. 1, Ocena sytuacji operacyjnej na odcinku kleru parafialnego diecezji sandomierskiej oraz kierunkowy plan operacyjnych przedsięwzięć, Kielce, 6 X 1961 r., k. 36-42.

87. Informator "Janaszkiewicz" - kapłan pracujący na jednej z parafii diecezji sandomierskiej, podjął współpracę z bezpieką w 1955. AIPN Ki, sygn. 015/824, t. 5, Wykaz agentury wykorzystywanej po zagadnieniu kleru z diecezji sandomierskiej, Kielce, 30 XII 1959, k. 78.

88. Ks. Wincenty Młodożeniec - ur. 2 III 1902 w Dobrocicach. Święcenia kapłańskie przyjął 22 V 1927. W 1. 1946-1962 był proboszczem i dziekanem w Iłży. Zmarł 2 XII 1984. KDS 80 (1987), s. 48-48a (3 s. okładki). Został pozyskany do współpracy z bezpieką w lipcu 1953 r. Deklarację o współpracy podpisał 31 III 1954. Występował pod pseudonimem "Ul" oraz „Wąkop" (nr rej. 1911, 483). Funkcjonariuszom aparatu bezpieczeństwa przekazywał wiele cennych informacji na temat Kurii Biskupiej w Sandomierzu oraz duchowieństwa diecezji sandomierskiej. Współpracował z SB do 22 III 1965, następnie traktowano go jako „kontakt poufny". B. Stanaszek, Działania aparatu bezpieczeństwa wobec Kurii diecezjalnej i seminarium duchownego w Sandomierzu w latach 1944-1956, w: Aparat represji wobec Kościoła w latach 1944-1956. Terytorium obecnej diecezji sandomierskiej, red. M. Krzysztofiński, J. Marecki, B. Stanaszek, Kraków 2012, s. 17-18; L. Gralak, Zwalczanie pielgrzymek pieszych przez instytucje państwa komunistycznego w ramach spraw obiektowych krypt. "Patnicy” w latach 1976-1989, Kraków 2014, praca doktorska (w zbiorach autora), s. 166.

89. Technika operacyjna "W" - kontrola korespondencji. Zob. M. Komaniecka, Wprowadzenie, w: Instrukcje pracy pionów pomocniczych Urzędu Bezpieczeństwa i Służby Bezpieczeństwa (1945-1989), wybór, wstęp i opr. M. Komaniecka, Kraków 2010, s. 50-63.

90. Technika operacyjna "T" - inwigilacja poprzez zastosowanie podsłuchów telefonicznych, pokojów, podglądów oraz tajnych przeszukań. Zob. M. Komaniecka, Wprowadzenie, dz. cyt, s. 35-50.

91. Jan Walaszczyk - funkcjonariusz aparatu bezpieczeństwa. W UB pracował od 1945 r., kwestiami kościoła Katolickiego zajmował się od 1957 r. B. Stanaszek, Diecezja sandomierska..., t. 1, dz. cyt., s. 122. 


\section{Bibliografia}

Archiwum Instytutu Pamięci Narodowej —Komisja Ścigania Zbrodni przeciw Narodowi Polskiemu, Delegatura w Kielcach, sygn. 015/819, 015/679, t. 1, 015/824, t. 1, 5 .

A. Dziurok, Wstęp, w: Metody pracy operacyjnej aparatu bezpieczeństwa wobec Kościołów i związków wyznaniowych 1945-1989, Warszawa 2004, s. 17-75.

R. Graczyk, Tropem SB. Jak czytać teczki, Kraków 2007.

L. Gralak, Zwalczanie pielgrzymek pieszych przez instytucje państwa komunistycznego w ramach spraw obiektowych krypt. "Patnicy" w latach 1976-1989, Kraków 2014, praca doktorska (w zbiorach autora).

R. Gryz, Państwo a Kościół w Polsce 1945-1956 na przykładzie województwa kieleckiego, Kraków 1999.

Instrukcja nr o3/55 o zasadach prowadzenia rozpracowania agenturalnego i ewidencji operacyjnej w organach bezpieczeństwa publicznego $P R L$, Warszawa, 11 III 1955 r., w: Instrukcje pracy operacyjnej aparatu bezpieczeństwa (1945-1989), oprac. i wstęp T. Ruzikowski, Warszawa 2004, s. 47-68.

Ł. Kamiński, Lingua securitatis, „Pamięć i Sprawiedliwość" 2003 nr 1 (3), s. 209-216.

M. Klocek, Prześladowanie duchowieństwa katolickiego w Końskich w latach 1939-1989, Końskie 2013.

M. Komaniecka, Wprowadzenie, w: Instrukcje pracy pionów pomocniczych Urzędu Bezpieczeństwa i Służby Bezpieczeństwa (1945-1989), wybór, wstęp i opr. M. Komaniecka, Kraków 2010, s. 17-69.

H. Konopka, Religia w szkołach Polski Ludowej. Sprawa nauczania religii w polityce państwa (1944-1961), Białystok 1997.

A. Kończak, Walenty Wójcik - biskup i profesor, "Studia Sandomierskie" 6 (1990-1996), s. 357-377.

S. Kowalik, Konflikt wyznaniowy w Wierzbicy. Niezależna parafia w polityce władz PRL (1962-1977), Lublin 2012.

"Kronika Diecezji Radomskiej".

"Kronika Diecezji Sandomierskiej". 
Materiały do instrukcji wydawniczej dla źródeł do dziejów najnowszych Polski, oprac. S. Kalabiński, F. Tych, Warszawa 1958 (maszynopis powielany).

G. Miernik, Wokół ustawy aborcyjnej z 1956 r., w: Zdrowie $i$ choroba.

Wpływ jakości życia na kulturę w Europie środkowej, red. A. Barciak, Katowice-Zabrze 2013, s. 348-375.

F. Musiał, Podręcznik bezpieki. Teoria pracy operacyjnej Służby

Bezpieczeństwa w świetle wydawnictw resortowych Ministerstwa Spraw Wewnętrznych PRL (1970-1989), Kraków 2007.

F. Musiał, Raj grabarzy narodu. Studia i materiały do dziejów aparatu represji w Polsce "ludowej" 1945-1989, Kraków 2010.

B. Noszczak, Przygotowania do Millenium Chrztu Polski i Tysiaclecia Państwa Polskiego (1965-1965), w: Millenium czy Tysiaclecie, red. B. Noszczak, Radom [2006], s. 11-38.

M. Pietrzak, Prawo wyznaniowe, Warszawa 1999.

B. Stanaszek, Diecezja sandomierska w powojennej rzeczywistości politycznej w latach 1945-1967, t. 1, Problematyka personalno-organizacyjna, Sandomierz 2006.

B. Stanaszek, Działania aparatu bezpieczeństwa wobec Kurii diecezjalnej i seminarium duchownego $w$ Sandomierzu w latach 1944-1956, w: Aparat represji wobec Kościoła w latach 1944-1956. Terytorium obecnej diecezji sandomierskiej, red. M. Krzysztofiński, J. Marecki, B. Stanaszek, Kraków 2012, s. 11-31.

B. Stanaszek, Księża diecezji sandomierskiej więzieni przez władze komunistyczne po II wojnie światowej, Rzeszów 2008.

B. Stanaszek, Usunać Biskupa! Władze PRL wobec Ordynariusza Diecezji Sandomierskiej Jana Kantego Lorka, Sandomierz 2004.

B. Stanaszek, „Wrogo ustosunkowany do naszego państwa”. Biskup Piotr Gołębiowski w dokumentach komunistycznej bezpieki i władz wyznaniowych, Sandomierz 2006.

B. Stanaszek, Nowakowski R., Słownik biograficzny księży diecezji sandomierskiej $X I X-X X$ w., t. 2, H-, , Sandomierz 2005.

J. Stefaniak, Postawy duchowieństwa w ocenie władz państwowych w latach apogeum stalinizmu (1948-1956), w: Społeczeństwo Państwo - Kościół (1945-20oo). Materiały z ogólnopolskiej konferencji naukowej, Szczecin, 15-16 VI 2000 r., red. A. Kawecki, K. Kowalczyk, A. Kubaj, Szczecin 2000, s. 17-20. 
R. Szczypta-Szczęch, Powiatowy Urząd Bezpieczeństwa Publicznego Opatów z siedziba w Ostrowcu Świętokrzyskim wobec Kościoła katolickiego w latach 1945-1955, w: Aparat represji wobec Kościoła w latach 1944-1956. Terytorium obecnej diecezji sandomierskiej, red. M. Krzysztofiński, J. Marecki, B. Stanaszek, Kraków 2012, s. 49-140.

J. Tandecki, K. Kopiński, Edytorstwo Źródeł Historycznych, Warszawa 2014. M. Truszczyński, PRL a Kościół rzymskokatolicki. Mechanizmy władzy, sposoby represji. Studium wybranych przypadków z lat 1944-1989, Szulborze Wielkie 2010.

Ustawa PRL z dnia 27 kwietnia 1956 r o warunkach dopuszczalności przerywania ciąży (Dz.U. PRL z 1956 Nr 12, poz. 61),

A. Warso, Represje paszportowe wobec biskupa Piotra Gołębiowskiego, "Studia Sandomierskie" 9 (2002), s. 485-499.

W. Wójcik, Ks. Jan Koceniak (1913-1984), "Studia Sandomierskie" 5 (1985), S. $492-505$.

Zarządzenie Ministra Oświaty z 19 sierpnia 1961 r. w sprawie prowadzenia punktów katechetycznych (Dz.Urz. Ministra Oświaty z 1961 Nr 10, poz. 124).

Zarzaddzenie nr oo114/63 ministra spraw wewnętrznych w sprawie prowadzenia ewidencji i dokumentowania działalności kleru katolickiego oraz instrukcja nr oo2/63 dyrektora Departamentu IV i dyrektora Biura "C" MSW o zasadach i trybie prowadzenia ewidencji i dokumentowania działalności kleru katolickiego, Warszawa, 6 VII 1946, oprac. Ł. Marek, w: Metody pracy operacyjnej aparatu bezpieczeństwa wobec Kościołów i zwiazków wyznaniowych 1945-1989, red. A. Dziurok, Warszawa 2004, s. 336-345.

Z. Zieliński, Duszpasterski aspekt obchodów Tysiąclecia Chrztu Polski, w: Kościół i Prymas Stefan Wyszyński 1956-1966, red. A. Dziurok, W. Wysocki, Katowice-Kraków 2008, s. 77-85. 


\section{Abstract}

Piotr Tylec

Surveillance of the Sandomierz diocese clergy in the light of a document

of the Kielce Voivodeship Police Headquarters of 6 October 1961.

This source edition presents a document created by the officers of the Security Service at the Voivodeship Police Headquarters in Kielce in October 1961 , containing information on the clergy of the Sandomierz diocese. It was kept as part of a case file entitled "Wisła" (surveillance of the diocesan curia and the seminary in Sandomierz). The document is a typical example of "counter-intelligence features of a case." In addition, it contains a "directional operational plan of undertakings". An analysis of the source allows us to determine the scale of surveillance to which the priests of the diocese were subjected. The present edition of the document contains a number of footnotes, which explain the more difficult formulations used by security officers, briefly approximate the figures of the priests named in it and elaborate on the state/Church relations in the Polish People's Republic.

\section{Keywords:} Security Service, Sandomierz diocese, surveillance of the clergy, repression of the Church. 


\title{
Abstrakt
}

\author{
Piotr Tylec \\ Inwigilacja duchowieństwa diecezji sandomierskiej w świetle \\ dokumentu KW MO w Kielcach z dnia 6 października 1961 roku.
}

\footnotetext{
Słowa kluczowe: Służby

Bezpieczeństwa, diecezja sandomierska, inwigilacja duchowieństwa, represje wobec Kościoła.
}

Niniejsza edycja źródłowa prezenuje dokument wytworzony przez funkcjonariuszy aparatu bezpieczeństwa KW MO w Kielcach w październiku 1961 r. Zawiera on informacje na temat duchowieństwa diecezji sandomierskiej. Został on opracowany w ramach teczki zagadnieniowej o kryptonimie „Wisła" (rozpracowanie Kurii Diecezjalnej w Sandomierzu i seminarium duchownego w tymże mieście). Dokument ten jest typową dla tych teczek "kontrwywiadowczą charakterystyką zagadnienia". Dodatkowo zawiera "kierunkowy plan operacyjnych przedsięwzięć". Analiza tego źródła pozwala na określenie skali inwigilacji, której zostali poddani kapłani wspomnianej diecezji. Prezentowany dokument zawiera wiele przypisów, które wyjaśniają trudniejsze sformułowania używane przez funkcjonariuszy bezpieki, skrótowo przybliżają sylwetki wymienionych w nim księży oraz rozwijają problematykę relacji państwo-Kościół w okresie PRL. 